\title{
Генетический анализ хлебопекарных качеств мягкой пшеницы
}

\author{
() А.А. Галимова ${ }^{1 *}$, Е.А. Заикина ${ }^{1}$, Н.И. Лещенко ${ }^{2}$, И.Д. Кузнецов ${ }^{3}$, Б.Р. Кулуев ${ }^{1}$ \\ ${ }^{1}$ Институт биохимии и генетики УФИЦ РАН \\ Россия, Республика Башкортостан, 450054, г. Уфра, Проспект Октября, д. 71, лит. \\ $1 E$.
}
${ }^{2}$ Башкирский научно-исследовательский институт сельского хозяйства УФИЦ РАН Россия, Республика Башкортостан, 450059, г. Уфра, ул. Р. Зорге, 19

${ }^{3}$ Башкирский государственный аграрный университет

Россия, Республика Башкортостан, 450001, е. Уфра, ул. 50 лет Октября, 34

*Email: aiz.galimova@yandex.ru

Хлебопекарные качества мягкой пшеницы тесно связаны с белковым составом зерна, который впоследствии определяет качество клейковины. В работе представлены результаты по выявлению аллелей генов высокомолекулярных глютенинов Glu-1 26 озимых сортов и линий Triticum aestivum L., районированных к условиям Предуральской степной зоны. Исследуемые образцы имели различия генотипов по субгеномам A и D, тогда как по субгеному В в локусе х типа все сортообразцы имели одинаковые аллели.

Ключевые слова: Triticum aestivum, мягкая пшеница, хлебопекарные качества, высокомолекулярные глютенины, гены глютенинов Glu-1

Качество клейковины является одним из основных составляющих при формировании высоких хлебопекарных качеств мягкой пшеницы. Клейковина образуется при участии двух типов белков - глиадинов и глютенинов [1]. Белки глиадины представляют собой простые, мономерные, низкомолекулярные белки, растворимы в спирте; глютенины являются высокомолекулярными белками с массой до нескольких десятков миллион дальтон и не растворимы в спирте [2]. При этом глютенины классифицируются на высокомолекулярные (HMW, high molecular weight) и низкомолекулярные (LMW, low molecular weight) [3]. Различия в молекулярных массах глиадинов и глютенинов обусловлены тем, что дисульфидные связи между остатками цистеина в глиадинах образуются в пределах одной молекулы, а в глютенинах - между разными молекулами. Основной каркас клейковины фоормируется за счет межмолекулярных дисульфидных связей между молекулами глютенинов, и, как результат, структура хлебобулочных изделий обеспечивается дисульфидными связями молекул глютенинов. Таким образом, субъединицы высокомолекулярного глютенина являются важными определяющими факторами качества пшеничного теста, поскольку они придают вязкоупругие свойства тесту, необходимому для замеса и выпечки. Обладая этой важной ролью, аллели генов высокомолекулярных глютенинов являются ключевыми маркерами в программах селекции. Гены глютенинов располагаются на хромосомах первой гомеологичной группы. При этом гены высокомолекулярных глютенинов обозначаются как Glu-1 (Glu-A1, GluB1, Glu-D1), а гены низкомолекулярных как Glu-3 (Glu-A3, Glu-B3, Glu-D3) [4]. Локусы высокомолекулярных субъединиц глютенинов кодируют полипептиды, образующие основную структуру клейковины за счет межмолекулярных дисульфидных связей. Для генов глютенинов характерны аллели, определяющие высокие и низкие показатели продуктивности, качества зерна, адаптивного потенциала [5]. 
В настоящей работе определены аллельные состояния локусов высокомолекулярных глютенинов Glu-A1, Glu-B1 и Glu-D1 у 26 озимых сортов и линий мягкой пшеницы, районированных к условиям Предуральской степной зоны. Для этого амплификацию локусов Glu-A1, Glu-B1 и Glu-D1 проводили с использованием праймеров UMN19 F/UMN19 R, Bx F/Bx R и UMN25 F/UMN25 R, UMN26 F/UMN26 R соответственно [6, 7]. Размеры ожидаемых ампликонов для праймеров UMN19 F/UMN19 R к субгеному А составляли 362 п.о. для аллелей а или с и 344 п.о. для аллеля $b$. Аллель а обуславливает наработку субъединицы 1 , аллель $b$ - субъединицы 2* и аллель c - субъединицы null. Субъединицы 1 и 2* оказывают положительное влияние на качество теста, субъединица null - отрицательное. Посредством ПЦР-амплификации выявлено, что из числа исследуемых 5 образцов аллель $b$ несут сорта Волжская качественная, Московская 39, Новоершовская и линии лютесценс 65752, лютесценс 67750, остальные исследуемые сортообразцы несут аллель а или с гена Glu-A1 (табл. 1). Анализ состава глютенинов, обусловленных субгеномом В, проводили с помощью маркера Вх7. Функциональная значимость этого маркера была оценена путем измерения основных свойств теста 156 линий пшеницы. Butow и др. [6] была показана сильная связь между линиями с избыточной экспрессией Bx7 и высокой прочностью теста. Генотипирование исследуемых сортообразцов посредством праймеров Bx F/Bx R выявило отсутствие различий по локусу $\mathrm{x}$ типа субгенома В - все исследуемые сорта и линии озимой мягкой пшеницы несут аллель, обуславливающий наработку субъединицы Bx7. Анализ генома D проводили с использованием праймеров к дуплексной ПЦР для одновременного выявления аллелей генов, кодирующих субъединицы Dx5 и Dy10 (5+10) и Dx2 и Dy12 (2+12). При использовании данных праймеров для образцов с субъединицами 5+10 наблюдали наличие ампликонов 397 и 281 п.о. (аллель d), с субъединицами 2+12 - ампликонов 415 и 299 п.о. (аллель а). Известно, что аллель $d$ локуса Glu-D1 (при наличии которого синтезируются субъединицы 5 и 10) имеет выраженное положительное влияние на качество муки. Тогда как распространенный аллель а (субъединицы 2 и 12) оказывает негативное влияние на получение качественного формового хлеба, однако рекомендуется для сортов, которые используются для изготовления подового хлеба, лапши и кондитерских изделий. В ходе настоящей работы выявлено, что из всей совокупности исследуемых сортообразцов 2 линии (лютесценс 65752 и лютесценс 67750) имеют аллель $а$, остальные несут аллель $d$ (табл. 1).

В настоящее время доказано существование тесной корреляционной зависимости между присутствием/отсутствием определенных аллелей локусов Glu-1 и показателями хлебопекарного качества. Известно, что сильное влияние на качество муки пшеницы оказывают аллели локуса Glu-D1. Следующими по влиянию являются аллели локусов Glu-B1 и Glu-A1 [8]. Аллельные варианты высокомолекулярных глютенинов 1A1, 1A2*, 1B 7+8, 1B 77+8, 1D 5+10 определяют высокие показатели качества зерна и хлебопекарных свойств пшеницы [7].

Таблица 1. Распределение аллелей генов Glu-1 в сортах и линиях мягкой пшеницы Предуральской степной зоны.

\begin{tabular}{|c|c|c|c|c|}
\hline \multirow{2}{*}{ № } & Сорт/линия & \multicolumn{3}{|c|}{ Аллели гена Glu-1 } \\
\cline { 3 - 5 } & & $\begin{array}{c}\text { Субгеном A } \\
\text { Glu-A1 }\end{array}$ & $\begin{array}{c}\text { Субгеном B } \\
\text { Glu-B1 }\end{array}$ & $\begin{array}{c}\text { Субгеном D } \\
\text { Glu-D1 }\end{array}$ \\
\hline 1 & Агидель & $a / c$ & $\mathrm{Bx7}$ & $d$ \\
\hline 2 & Агидель H & $a / c$ & $\mathrm{Bx7}$ & $d$ \\
\hline 3 & Агидель 2 & $\mathrm{a} / \mathrm{c}$ & $\mathrm{Bx7}$ & $d$ \\
\hline 4 & Алабасская & $\mathrm{a} / \mathrm{c}$ & $\mathrm{Bx7}$ & $d$ \\
\hline 5 & Анастасия & $\mathrm{a} / \mathrm{c}$ & $\mathrm{Bx7}$ & $d$ \\
\hline 6 & Аэлита & $\mathrm{a} / \mathrm{c}$ & $\mathrm{Bx7}$ & $d$ \\
\hline
\end{tabular}




\begin{tabular}{|c|c|c|c|c|}
\hline 7 & Башкирская 10 & $a / c$ & $\mathrm{~B} \times 7$ & $d$ \\
\hline 8 & Безенчукская 380 & $a / c$ & Bx7 & $d$ \\
\hline 9 & Волжская качеств. & $b$ & Bx7 & $d$ \\
\hline 10 & Калач 60 & $a / c$ & $\mathrm{Bx} 7$ & $d$ \\
\hline 11 & Лана & $a / c$ & $\mathrm{~B} \times 7$ & $d$ \\
\hline 12 & Московская 39 & $b$ & Bx7 & $d$ \\
\hline 13 & Новоершовская & $b$ & $\mathrm{Bx7}$ & $d$ \\
\hline 14 & Уфимка & $a / c$ & $\mathrm{Bx} 7$ & $\bar{d}$ \\
\hline 15 & Лютесценс 25520 & $a / c$ & $\mathrm{Bx} 7$ & $d$ \\
\hline 16 & Лютесценс 47488 & $a / c$ & $\mathrm{~B} \times 7$ & d \\
\hline 17 & Лютесценс 60865 & $a / c$ & $\mathrm{Bx} 7$ & $d$ \\
\hline 18 & Лютесценс 65532 & $a / c$ & $\mathrm{Bx} 7$ & $\bar{d}$ \\
\hline 19 & Лютесценс 65737 & $a / c$ & $\mathrm{Bx} 7$ & $d$ \\
\hline 20 & Лютесценс 65752 & $b$ & $B \times 7$ & $a$ \\
\hline 21 & Лютесценс 67750 & $b$ & $B \times 7$ & $a$ \\
\hline 22 & Эритроспермум 37067 & $a / c$ & $\mathrm{Bx} 7$ & d \\
\hline 23 & Лютесценс 68347 & $a / c$ & $\mathrm{Bx} 7$ & $d$ \\
\hline 24 & Лютесценс 68551 & $a / c$ & $\mathrm{Bx} 7$ & $d$ \\
\hline 25 & Эритроспермум 69577 & $a / c$ & $\mathrm{Bx} 7$ & d \\
\hline 26 & Эритроспермум 70757 & $a / c$ & $\mathrm{~B} \times 7$ & $d$ \\
\hline
\end{tabular}

Таким образом, в ходе молекулярно-генетического анализа сортов и линий озимой мягкой пшеницы, районированных к условиям Предуральской степной зоны, был исследован полиморфизм сортообразцов по генам высокомолекулярных глютенинов Glu1 посредством ПЦР-амплификации и визуализации результатов по конечной точке. Среди 26 изученных сортов и линий озимых форм $T$. aestivum выявлены различия по геномам A и D. Преобладающее большинство исследуемых сортов и линий имели генотипы с аллелями $a / c, B \times 7, d$ для геномов A, B и D соответственно (для субгенома B указана суъединица глютенина. Установление достоверного аллеля требует дополнительных исследований). У 3 сортов выявлены аллели $b$ в геноме A (по геномам B и D так же несут аллели Bx7, d): Волжская качественная, Московская 39, Новоершовская. Наконец, у двух линий (лютесценс 65752 и лютесценс 67750) выявлены аллели $b$ генома $\mathrm{A}$ и аллель а генома $\mathrm{D}$, которые являются редкими для исследуемой группы сортов и линий озимой мягкой пшеницы. Итак, по полученным результатам сочетание аллелей генов высокомолекулярных глютенинов Glu-1 сортов Волжская качественная, Московская 39, Новоершовская представляется наиболее благоприятным для формирования высоких хлебопекарных качеств зерна.

Работа выполнена в рамках государственного задания № AAAA-A19-119021190011-0.

\section{Литература}

1. Чеботарь С.В., Благодарова Е.М., Куракина Е.А. и др. Генетический полиморфизм локусов, определяющих хлебопекарное качество украинских сортов пшеницы // Вавиловский журнал генетики и селекции. 2012. T. 16. С. 87-98.

2. D'Ovidio R., Masci S. The low molecular weight glutenin subunits of wheat gluten // J. Cereal Sci. 2004. V. 39. P. 321-339.

3. Shewry P., Halford N. Cereal seed storage proteins: structures, properties and role in grain utilization // Journal of experimental botany. 2002. V. 53. P. 947-958. 
4. Zhang W., Gianibelli M., Rampling L. Characterisation and marker development for lowmolecular weight glutenin genes from Glu-A3 alleles of bread wheat (Triticum aestivum L.) // Theoretical and Applied Genetics. 2004. V. 108. P. 1409-1419.

5. Конарев А.В., Конарев В.Г., Губарева Н.К., др. Белки семян как маркеры в решении проблем генетических ресурсов растений, селекции и семеноводства // Цитология и генетика. 2000. Т. 34. С. 91-104.

6. Butow B.J., Ma W., Gale K.R., et al. Molecular discrimination of Bx7 alleles demonstrates that a highly expressed high-molecular-weight glutenin allele has a major impact on wheat flour dough strength // Theoretical and Applied Genetics. 2003. V. 107. P. 1524-32.

7. Сичкарь С.М., Великожон Л.Г., Дубровная О.В. Молекулярно-генетический анализ и хлебопекарные качества гибридов Triticum spelta L. × Triticum aestivum L. // Молекулярная и прикладная генетика. 2017. Т. 22. С. 96-103.

8. Boisson M., Mondon K., Torney V. Partial sequences of nitrogen metabolism genes in hexaploid wheat // Theoretical and Applied Genetics. 2005. V. 110. P. 932-940.

\title{
Genetic analysis of bread wheat baking qualities
}

\author{
A. A. Galimova ${ }^{1 *}$, E. A. Zaikina1, N. I. Leshchenko², I. D. Kuznetsov³ , B. R. Kuluev \\ ${ }^{1}$ Institute of Biochemistry and Genetics UFRC RAS \\ 71 Prospekt Oktyabrya, 450054 Ufa, Republic of Bashkortostan, Russia. \\ ${ }^{2}$ Bashkir Agriculture Research Institute UFRC RAS \\ 19 Zorge street, 450059 Ufa, Republic of Bashkortostan, Russia. \\ ${ }^{3}$ Bashkir State Agrarian University \\ 34 50-letiia Octiabria street, 450059 Ufa, Republic of Bashkortostan, Russia.
}

\section{*Email: aiz.galimova@yandex.ru}

The baking qualities of bread wheat are closely related to the protein composition of the grain, which subsequently determines the quality of gluten. The work presents the results on the identification of high molecular weight glutenins Glu-1 genes alleles of 26 winter varieties and lines of Triticum aestivum L., zoned to the conditions of the pre-Ural steppe zone. The studied samples had differences in genotypes for the A and D genomes, while for the $x$ type locus on B genome all cultivars had the same alleles.

Keywords: Triticum aestivum L., bread wheat, baking quality, high molecular weight glutenins, glutenin genes Glu-1 